\title{
Scaled Semivariogram in the Sample Planning of Soils Cultivated With Sugarcane
}

\author{
José Eduardo Sória ${ }^{1}$, Renan Francisco Rimoldi Tavanti ${ }^{2}$, Marcelo Alves ${ }^{3}$, Marcelo Andreotti ${ }^{2}$ \\ \& Rafael Montanari ${ }^{2}$ \\ ${ }^{1}$ Centro Universitário Católico Salesiano, Lins, SP, Brazil \\ ${ }^{2}$ São Paulo State University “Julio de Mesquita Filho”, Ilha Solteira, SP, Brazil \\ ${ }^{3}$ Universidade do Oeste Paulista, Presidente Prudente, SP, Brazil \\ Correspondence: Renan Francisco Rimoldi Tavanti, Department of Plant Protection, Rural Engineering and Soil, \\ São Paulo State University “Julio de Mesquita Filho" (UNESP), Passeio Monção, 226-Centro, Ilha Solteira, São \\ Paulo, Brazil. Tel: 55-(18)-3743-1142. E-mail: renan.tavanti91@gmail.com
}

$\begin{array}{lc}\text { Received: May 21, } 2018 & \text { Accepted: June 28, } 2018 \quad \text { Online Published: August 15, } 2018 \\ \text { doi:10.5539/jas.v10n9p315 } & \text { URL: https://doi.org/10.5539/jas.v10n9p315 }\end{array}$

\begin{abstract}
Sugarcane cultivation has expanded in areas previously occupied by degraded pastures. In the first years of cultivation, besides the physical and chemical restrictions of the soils, other factors can make impossible the maximum productive expression of the crop, like the climatic and edaphic factors. The objective of this work was to evaluate the ideal sampling density and spatial variability of the physical and chemical attributes of soils cultivated with sugarcane. Georeferenced data provided by the Sugarcane Technology Center (STC) of an area of approximately 19,000 hectares located in the northwest region of São Paulo were evaluated. The granulometric fractions of the soils and organic matter contents and base saturation were determined at depths of $0.00-0.25$ and 0.25-0.50 m. An index named edaphic environment (ENV) was calculated based on the records of rainfall of the areas and the productivity of the sugarcane, being represented with aptitude scores ranging from 0 (worst condition) to 10 (best condition). The results showed a strong correlation between clay and organic matter attributes with ENV index. Regions with aptitude $\geq 6.65$ of ENV index corresponded to sites with clay (CL) and organic matter (OM) content above $335 \mathrm{~g} \mathrm{~kg}^{-1}$ and $30 \mathrm{~g} \mathrm{~kg}^{-3}$, respectively. Only $10.86 \%$ of the area presented base saturation (V\%) concentration $\geq 68 \%$, correlating positively with $\mathrm{CL}$ and ENV. Through the scaled semivariogram it was possible to verify that a density of sampling of a sample to each 18 ha can be used for a mapping in macroscale of the evaluated attributes in the northwest region of the state of São Paulo.
\end{abstract}

Keywords: geostatistics, spatial variability, production environments, Saccharum spp.

\section{Introduction}

Brazil is among the countries designed to meet the growing demand for food and biofuels in the next four decades (Strassburg et al., 2014). Among the segments of its economy, the production of sugarcane has a relevant socioeconomic role, due to the production of ethanol, as a source of renewable energy, and in natura, for animal feed and sugar and alcohol manufacture.

It is estimated that ethanol production from sugarcane increases from 21 to 61.6 billion liters by 2021, consequently, 6.4 million hectares of planted area will be needed to meet this demand (Goldemberg et al., 2014). Currently, the state of São Paulo is the largest Brazilian producer, with 4558.6 thousand hectares of planted area and average productivity of $77,268 \mathrm{~kg} \mathrm{ha}^{-1}$ (CONAB, 2017).

The expansion of this crop in recent years has occurred mainly in the northwest region of the state, where small rural properties are leased by sugar and alcohol mills in the region. Such a condition can be justified by the inefficiency in the income transformation of small farmers who practice extensive livestock farming. The poor management of livestock and the low natural fertility of soils do not favor the maximum productive expression of the pastures, which directly infers in the erosive process of the soil that culminates with the degradation (Garbiate et al., 2011). This situation reinforces the need to adopt specific management practices for the production of sugarcane in these areas (Crusciol et al., 2014). 
The knowledge of the spatial variability of the physical and chemical attributes of the soils helps in the planning and evaluation of risks for the decision making in the management of the plantations. The so-called edaphic factors are important to define production environments through the soil's agricultural potential (Cavalcante and do Prado, 2010). However, the level of detail and costs of sampling the soil for sugarcane cultivation are high. Tools applied to the study of spatial variability have been presented in an advantageous way to analyze the punctual information of the soil and its spatial dependence with the productivity of the sugarcane (Oliveira et al., 2013).

In the state of São Paulo, the main macro-scale study of soil attributes was carried out by the state environmental agency CETESB $(2008,2015)$, in which the hydrographic basins of Alto Tietê, Rio Piracicaba, Capivari and Jundiaí were characterized. Although these data were not interpolated, the agency used indexes to estimate soil quality in terms of class, use and occupation. This information can meet some public requirements and assist in agricultural and urban management. However, for agriculture, values that cover spatial variability at a higher level of detail are needed (Liu et al., 2013). Moreover, studies on the ideal sampling density to characterize the spatial variability of soil attributes are extremely important and often scarce (Marques Júnior et al., 2006; Montanari et al., 2012).

This work had the objective of evaluating the ideal sampling density and spatial variability of the physical and chemical attributes of the soils cultivated with sugarcane. In addition, characterize dependence and correlate soil attributes with production environments for sugarcane.

\section{Materials and Methods}

The work was developed in the northwest region of the State of São Paulo, Brazil, between latitudes $20^{\circ} 20^{\prime} 20^{\prime \prime}$ and $20^{\circ} 45^{\prime} 51^{\prime \prime}$ South and longitudes $51^{\circ} 01^{\prime} 10^{\prime \prime}$ and $51^{\circ} 31^{\prime} 30^{\prime \prime}$ West. The climate of the region, according to the classification of Köppen, is defined as Aw, tropical humid with rainy season in summer and dry in winter and temperature ranging between 26.8 and $21.2{ }^{\circ} \mathrm{C}$. The average annual rainfall is $1128 \mathrm{~mm}$ with the highest occurrence in the period from November to February.

The study area is predominantly on the Bauru Group formations (Adamantina and Santo Anastácio), which presents the sandstone as the main rock. Near the banks of the Paraná, São José dos Dourados and Tietê rivers, there is the outcrop of basalt, belonging to the Serra Geral formation of the São Bento Group (IPT, 1981). The main soils of the region are the eutrophic (base saturation $>50 \%$ ) and dystrophic (base saturation $<50 \%$ ) Red Oxisols with texture varying between middle and clayey classes of ferric character near the river banks (Demattê, 1980). It is also observed the occurrence of eutrophic and dystrophic Red Argisols and Red-Yellow Argisols (Ultisols, USDA Soil Taxonomy), with a sandy to medium-clayey texture, respectively (Comissão de Solos, 1960).

Data from the last seven years were collected from an area of 18,693 hectares of the Soil Survey Department of the Sugarcane Technology Center (STC) in the northwest region of the State of São Paulo. The information was extracted from 638 georeferenced sample points belonging to a randomly distributed non-regular grid (Figure 1).

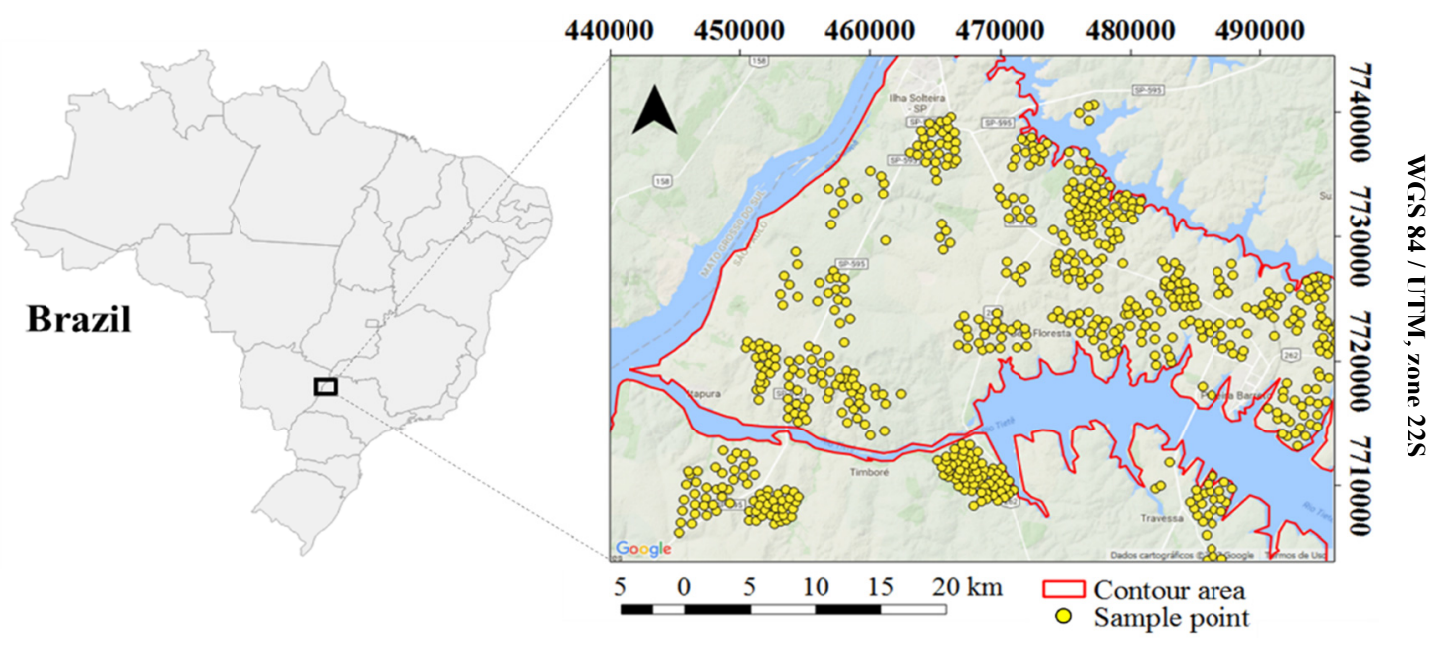

Figure 1. Location of the area and sampling points (adapted from Google Earth) 
The collections were made in sugarcane cultivation areas with different ages of cut. The soil was sampled between the rows of the culture in two layers $(0.00-0.25$ and $0.25-0.50 \mathrm{~m})$, which were submitted separately to chemical and physical analytical determinations. In the laboratory, soil particle fractions were determined: clay (CL), silt (ST) and sand (SD) by pipette method (Embrapa, 2011), and organic matter (OM) and base saturation (V\%), by the methods proposed by Van Raij et al. (2001).

With the aid of the Brazilian Soil Classification System (Embrapa, 2013) and agro-environmental zoning for the sugar-alcohol sector proposed by Cavalcante and Prado (2010), it was possible to calculate the edaphic environment index (ENV) for the cultivation of sugarcane, according to the methodology adapted by the STC.

As an example of the framing of the Latosols (Oxisols, USDA Soil Taxonomy) and Argisols in the classes of ENV, we can mention: Latossolos eutróficos of clay texture, classified as environment " $A$ " in which it is attributed scores between 9 and 10 (Figure 2). Those of average texture with clay contents varying between 150 $\mathrm{g} \mathrm{kg}^{-1}$ at $250 \mathrm{~g} \mathrm{~kg}^{-1}$ and of alic character, are classified as environment " $\mathrm{D}$ ", scores 3 to 4.99 . For the Argisols that presented sandy/medium-clayey binary texture (horizon A $+\mathrm{E} /$ horizon B) of dystrophic character, they are also classified as environment "D". However, similar Argisols with higher clay content in depth (medium-clay texture: $150 \mathrm{~g} \mathrm{~kg}^{-1}$ at $250 \mathrm{~g} \mathrm{~kg}^{-1}$ ), have a higher potential, classified as " $\mathrm{C}$ " environment, with a score between 5 and 6.99 .

\begin{tabular}{|c|c|c|c|c|c|}
\hline \multirow{8}{*}{$\begin{array}{l}\quad \text { Order } \\
\text { 1. Argissolo } \\
\text { 2. Cambissolo } \\
\text { 3. Chernossolo } \\
\text { 4. Espodossolo } \\
\text { 5. Gleissolo } \\
\text { 6. Latossolo } \\
\text { 7. Luvissolo } \\
\text { 8. Neossolo } \\
\text { 9. Nitossolo } \\
\text { 10. Organossolo } \\
\text { 11. Planossolo } \\
\text { 12. Vertissolo }\end{array}$} & \multirow{2}{*}{ Big group } & \multirow[b]{2}{*}{ Horizon A } & \multirow[b]{3}{*}{ Climatic zoning } & & \multirow{3}{*}{$\begin{array}{l}\text { Edaphic environmen } \\
\text { index (ENV) for the } \\
\text { cultivation of } \\
\text { sugarcane }\end{array}$} \\
\hline & & & & & \\
\hline & \multirow{5}{*}{$\begin{array}{l}\text { 1. Eutrófico } \\
\text { 2. Mesotrófico } \\
\text { 3. Mesoálico } \\
\text { 4. Distrófico } \\
\text { 5. Ácrico } \\
\text { 6. Álico } \\
\text { 7. Alumínico } \\
\text { 8. Alítico }\end{array}$} & $\begin{array}{l}\text { 1. Sandy } \\
\text { 2. Medium clayey }\end{array}$ & & & \\
\hline & & $\begin{array}{l}\text { 3. Clayey } \\
\text { 4. Very clayey }\end{array}$ & \multirow{3}{*}{$\begin{array}{l}\text { 1. Climatic potential I } \\
\text { 2. Climatic potential II } \\
\text { 3. Climatic potential III } \\
\text { 4. Climatic potential IV } \\
\text { 5. Climatic potential V }\end{array}$} & \multirow[b]{2}{*}{$\begin{array}{l}\text { Productivity } \\
\text { expectation }\end{array}$} & 1. ENVA \\
\hline & & \multirow{4}{*}{$\begin{array}{l}\text { Horizon B } \\
\text { 1. Sandy } \\
\text { 2. Medium clayey } \\
\text { 3. Clayey } \\
\text { 4. Very clayey }\end{array}$} & & & 3. ENV C \\
\hline & & & & & 5. ENVE \\
\hline & & & \multirow[t]{2}{*}{ Source: Cavalcante and do Prado (2010) } & & \\
\hline & \multirow[t]{2}{*}{ Source: Embrapa (2013) } & & & & \\
\hline Source: Embrapa (2013 & & mbrapa (2013) & mpled in the p & & \\
\hline
\end{tabular}

Figure 2. Illustration of the scheme to define the edaphic environment index (ENV) for the cultivation of sugarcane

The water balance and relative water consumption for the sugarcane crop were determined for a period of five years from 2012 to 2016 (totaling four harvests) due to the availability of meteorological data obtained by the Agrometeorological Network of the Northwest region and accessible through the Climate Channel of UNESP Ilha Solteira (http://clima.feis.unesp.br) from the Station.

The edaphic environment for the sugarcane production is also related to the soil water reserve capacity. The high clay content in the soil depth positively influences the availability of water during periods of lower rainfall in the region. The classes of ENV under different climatic conditions as a function of the expected productivity of sugarcane were calculated according to Cavalcante and do Prado (2010). At the end of the scores assignments, the ENV index was calculated by the overall mean of the properties described in Figure 2.

For descriptive statistical analysis of the data, the mean, median, minimum and maximum values, standard deviation, coefficient of variation, kurtosis and asymmetry were calculated. Then, the frequency distribution of the data was verified by evaluating the proximity between the mean and median values and asymmetry and kurtosis coefficients. The coefficient of variation (CV) was classified according to Pimentel-Gomes and Garcia (2002). Subsequently, the Pearson correlation matrix was performed for the two-to-two combinations between the attributes studied.

The spatial dependence of the data was evaluated by the geostatistical analysis, in which the theoretical semivariograms were calculated, according to Equation 1:

$$
\hat{\gamma}(h)=\frac{1}{2 N(h)} \sum_{i=1}^{N(h)}\left[Z\left(X_{i}\right)-Z\left(X_{i}+h\right)\right]^{2}
$$

where, $\gamma(\mathrm{h})$ is the estimated semivariance; $\mathrm{N}(\mathrm{h})$ the pairs of values measured by the distance $\mathrm{h}$; $\mathrm{Z}(\mathrm{Xi})$ is the value of the variable $\mathrm{Z}$ at the point $\mathrm{Xi}$ and $\mathrm{Z}(\mathrm{Xi}+\mathrm{h})$ is the variable value $\mathrm{Z}$ at the point $\mathrm{Xi}+\mathrm{h}$. The distance vector $(\mathrm{h})$ is given in meters. 
The exponential (Equation 2), spherical (Equation 3) and Gaussian (Equation 4) semivariogram models were tested, and the selection criteria were: a) the smallest sum of the squares of the deviations (SQD); b) the highest spatial dependence coefficient $\left(\mathrm{R}^{2}\right)$ and $\mathrm{c}$ ) the highest spatial dependence degree. The final decision of the adjustment model to be considered was based on the cross-validation of the data observed and estimated by the model, as well as the definition of the neighborhood size of points that would provide the best interpolation for ordinary kriging. The analysis of the Spatial Dependence Evaluator (SDE) and its classification was performed according to Montanari et al. (2010).

$$
\begin{gathered}
\hat{\gamma}(h)=C_{0}+C\left\{1-\exp \left[-3\left(\frac{h}{A_{0}}\right)\right]\right\} ; h>0 \\
\hat{\gamma}(h)=C_{0}+C\left[\frac{3}{2}\left(\frac{h}{A_{0}}\right)-\frac{1}{2}\left(\frac{h}{A_{0}}\right)^{3}\right] ; 0 \leq h \leq A_{0} \text { then } \hat{\gamma}(h)=C_{0}+C ; h \geq A_{0} \\
\hat{\gamma}(h)=C_{0}+C\left\{1-\exp \left[-3\left(\frac{h^{2}}{A_{0}}\right)\right]\right\} ; 0<h<d
\end{gathered}
$$

where, $\gamma(\mathrm{h})$ is the estimated semivariance; $\mathrm{C}_{0}$ is the pure nugget effect; $\mathrm{C}$ is the contribution of semivariance; $\mathrm{A}_{0}$ is the range $(\mathrm{m})$ and $\mathrm{h}$ is the distance vector $(\mathrm{m}) ; \mathrm{d}$ corresponds to the maximum distance analyzed.

The theoretical semivariograms were scaled by dividing the semivariance by statistical variance (Ceddia et al., 2009; Comegna \& Basile, 1994; Ferreyra et al., 2002; Vieira et al., 1981). The choice of the scaled semivariogram model that best fit the data was based on the higher $\mathrm{R}^{2}$ and the smaller sum of squares of the residues, generated from the observed and estimated data, besides the practical knowledge of the behavior of the assessed attributes. Subsequently the scaled semivariogram served as the basis for calculating the minimum number of soil samples (Oliveira et al., 2014, 2015), according to Equation 5:

$$
N=\frac{\alpha}{A_{0}^{2} / 10000}
$$

where, $\mathrm{N}$ is the minimum number of samples required for the determination of a sampling mesh in an area $\alpha$ (ha).

\section{Results and Discussion}

The results showed a high variability of the silt (ST) and clay (CL) in both layers evaluated, with coefficients of variation (CV) above $45 \%$ (Table 1). These CV values can be justified by the diversity of soil classes and their particle size distribution present in the northwest region of São Paulo (IPT, 1981). CL ranged from 30 to $730 \mathrm{~g}$

\begin{tabular}{|c|c|c|c|c|c|c|c|c|}
\hline \multirow{2}{*}{ Atributtes } & \multirow{2}{*}{ Average } & \multirow{2}{*}{ Median } & \multicolumn{2}{|c|}{ Value } & \multirow{2}{*}{ SD } & \multicolumn{3}{|c|}{ Coefficient } \\
\hline & & & Maximum & Minimum & & Var. & Kurtosis & Asym \\
\hline \multicolumn{9}{|c|}{ Soil depth $0.00-0.25 \mathrm{~m}$} \\
\hline CL1 $\left(\mathrm{g} \mathrm{kg}^{-1}\right)$ & 713 & 749 & 915 & 190 & 125 & 17.6 & 2.62 & -1.58 \\
\hline ST1 $\left(\mathrm{g} \mathrm{kg}^{-1}\right)$ & 89 & 81 & 380 & 10 & 45 & 50.5 & 5.69 & 1.66 \\
\hline $\mathrm{SD} 1\left(\mathrm{~g} \mathrm{~kg}^{-1}\right)$ & 199 & 180 & 650 & 30 & 102 & 51.5 & 2.45 & 1.46 \\
\hline OM1 $\left(\mathrm{g} \mathrm{kg}^{-1}\right)$ & 20 & 18 & 81 & 5 & 8 & 41.7 & 5.84 & 1.72 \\
\hline V\%1 & 60 & 61 & 94 & 15 & 16 & 26.0 & -0.56 & -0.20 \\
\hline \multicolumn{9}{|c|}{ Soil depth $0.25-0.50 \mathrm{~m}$} \\
\hline CL2 $\left(\mathrm{g} \mathrm{kg}^{-1}\right)$ & 671 & 706 & 877 & 110 & 134 & 20.0 & 1.87 & -1.39 \\
\hline ST2 $\left(\mathrm{g} \mathrm{kg}^{-1}\right)$ & 89 & 83 & 282 & 10 & 40 & 45.2 & 2.16 & 1.08 \\
\hline $\mathrm{SD} 2\left(\mathrm{~g} \mathrm{~kg}^{-1}\right)$ & 241 & 215 & 730 & 26 & 118 & 59.0 & 1.96 & 1.33 \\
\hline OM2 $\left(\mathrm{g} \mathrm{kg}^{-1}\right)$ & 13 & 12 & 40 & 4 & 5 & 37.2 & 2.69 & 1.34 \\
\hline $\mathrm{V} \% 2$ & 56 & 57 & 90 & 9 & 16 & 28.9 & -0.44 & -0.25 \\
\hline \multicolumn{9}{|c|}{ Edaphic environment } \\
\hline ENV & 5.3 & 5.0 & 9.0 & 1.0 & 1.8 & 34.2 & 0.14 & 0.33 \\
\hline
\end{tabular}
$\mathrm{kg}^{-1}$ and ST from 10 to $380 \mathrm{~g} \mathrm{~kg}^{-1}$, considering the two evaluated layers (Table 1).

Table 1. Descriptive analysis of the production environment for the sugarcane crop and the soil attributes analyzed in the 0 to 0.25 and 0.25 to $0.50 \mathrm{~m}$

Note. ENV, SD, ST, CL, OM and $\mathrm{V} \%$ are respectively the production environment, sand, silt, clay, organic matter and base saturation values in the $0.00-0.25 \mathrm{~m}$ layer when followed by the number 1 and in the layer $0.25-0.50 \mathrm{~m}$ when followed by the number 2; SD, Var. and Assm. are respectively the standatd deviation and coefficients of variation (\%) and asymmetry. 
Soil organic matter $(\mathrm{OM})$ was classified as medium in the superficial layer $0-0.25 \mathrm{~m}\left(20 \mathrm{~g} \mathrm{~kg}^{-1}\right)$, and low in the sub-superficial layer $0.25-0.50 \mathrm{~m}\left(13 \mathrm{~g} \mathrm{~kg}^{-1}\right)$ (Table 1). Although these values are unsatisfactory for sugarcane cultivation, the respective CVs of $41.7 \%$ and $37.2 \%$ indicated the existence of sites with values up to $81 \mathrm{~g} \mathrm{~kg}^{-1}$, which are classified as very high. The mechanized harvesting of sugarcane provides great deposition of residues on the soil surface, however, Segnini et al. (2013) reported in their studies that the incorporation of straw in the conventional soil preparation does not improve the accumulation of $\mathrm{OM}$, as well as the carbon stocks and its quality. Therefore, conventional management may not be feasible for the maintenance of OM in the superficial layers of the soil, causing high spatial variability.

The sand (SD) and base saturation (V\%) contents presented low CV values in comparison to the other attributes, classified as medium $<35 \%$ (Table 1). The mean $\mathrm{V} \%$ was $60 \%$ in the $0-0.25$ layer and $56 \%$ in the $0.25-0.50 \mathrm{~m}$ layer, indicating soil profiles with constructed fertility.

In the overall mean, the ENV index was 5.3 and its CV was classified as medium 34\%. According to the STC classification methodology, the region would be classified as production environment " $\mathrm{C}$ " for sugarcane cultivation, however, it can be inferred the existence of sites with index 1 and 9 according to minimum and maximum values (Table 1). It is evident the existence of sites with production environments " $A$ " and " $E$ " and a local investigation is necessary in order to identify the limiting factors of production, thus defining specific management zones.

All attributes presented average values close to the median, however, only ENV index, V\%1 and V\%2 presented values of asymmetry and kurtosis close to zero, being considered the only attributes with symmetric frequency distributions (Table 1).

Significant linear correlations of the ENV index with all attributes were observed, being positive with the contents of ST, CL, OM, V\%, and negative with SD (Table 2). Among the coefficients obtained, there was a moderate correlation between the CL content and the ENV index in both evaluated layers, being, therefore, the attribute that most influenced the edaphic environment. It is understood that the CL content is directly linked to the inputs of $\mathrm{OM}$ and $\mathrm{V} \%$, in which the agricultural suitability of the soils favors the use of high technological level in the cultivation of sugarcane. This can be proved by the positive correlations between CL $\times \mathrm{OM}$ and $\mathrm{V} \%$, in which coefficients of $0.52^{* *}$ and $0.26^{* *}$ in the $0-0.25 \mathrm{~m}$ layer, and $0.41^{* *}$ and $0.30^{* *}$ in the layer of $0.25-0.50$ $\mathrm{m}$, respectively, were found (Table 2).

Table 2. Pearson correlation matrix and respective coefficients between production environment for sugarcane and soil attributes analyzed

\begin{tabular}{llllll}
\hline Atributtes & ENV & SD1 & ST1 & CL1 & OM1 \\
\hline Soil depth $0.00-0.25 m$ & & & & & \\
SD1 & $-0.67^{* *}$ & & & & \\
ST1 & $0.42^{* *}$ & $-0.65^{* *}$ & & & \\
CL1 & $0.64^{* *}$ & $-0.94^{* *}$ & $0.36^{* *}$ & & \\
OM1 & $0.43^{* *}$ & $-0.62^{* *}$ & $0.54^{* *}$ & $0.52^{* *}$ & \\
V\%1 & $0.40^{* *}$ & $-0.32^{* *}$ & $0.30^{* *}$ & $0.26^{* *}$ & $0.44^{* *}$ \\
\hline Atributtes & ENV & SD2 & ST2 & CL2 & OM2 \\
\hline Soil depth $0.25-0.50 m$ & & & & & \\
SD2 & $-0.68^{* *}$ & & & & \\
ST2 & $0.37^{* *}$ & $-0.53^{* *}$ & & & \\
CL2 & $0.65^{* *}$ & $-0.96^{* *}$ & $0.27^{* *}$ & & \\
OM2 & $0.38^{* *}$ & $-0.46^{* *}$ & $0.32^{* *}$ & $0.41^{* *}$ & \\
V\%2 & $0.55^{* *}$ & $-0.35^{* *}$ & $0.27^{* *}$ & $0.30^{* *}$ & $0.32^{* *}$ \\
\hline
\end{tabular}

Note. ENV, SD, ST, CL, OM and $\mathrm{V} \%$ are respectively the production environment, sand, silt, clay, organic matter and base saturation values in the $0.00-0.25 \mathrm{~m}$ layer when followed by the number 1 and in the layer $0.25-0.50 \mathrm{~m}$ when followed by the number 2 ; ** significant at $1 \%$ probability.

As for the SD content, this was negatively correlated with all attributes. It is understood that SD is related to lower water retention (Zhao et al., 2010) and low soil fertility (Souza et al., 2010), consequently lower availability of nutrients to the plants, not favoring the supply of soil OM. Souza et al. (2010), found low 
coefficients of linear correlation of the attributes $\mathrm{OM}$ and $\mathrm{V} \%$ with the productivity of the sugarcane cultivated in an Argisol. The authors attributed this fact to the points sampled at lower altitude $(<518.21 \mathrm{~m})$, which was due to the low input of organic matter in the 0.20-0.40 m layer of the soil. In the present study, it was observed that the ENV index was strongly influenced by soil SD content. The highest negative correlation of the index was due to SD content, where $-0.67^{* *}$ in the layer of $0.00-0.25$ and $-0.68^{* *}$ in the layer of $0.20-0.50 \mathrm{~m}$ (Table 2).

According to the geostatistical analysis, all variables presented spatial dependence with semivariograms adjusted to the exponential and spherical models (Figure 3). The spatial dependence evaluator (SDE) was classified as moderate for CL1, CL2, SD1, SD2, ST1, ST2, OM1, OM2, V\%2, ENV index attributes, and high for V\%1, with a representativity of $50.02 \%$ to $75.84 \%$ of the nugget effect $\left(\mathrm{C}_{0}\right)$ in the definition of the threshold of semivariance $\left(\mathrm{C}_{0}+\mathrm{C}\right)$. The high values of $\mathrm{C}_{0}$ can be justified by the similarity between points observed at short distances, showing that the spatial distribution of attributes is essentially homogeneous. Vieira et al. (2011) also obtained a high $\mathrm{C}_{0}$ for the semivariograms of clay and total sand contents, evaluating an Oxisol of the municipality of Angatuba, São Paulo. The authors consider that this behavior is due to the minimum distance between points in the sampling grid, which made it impossible to detect lower variability patterns.
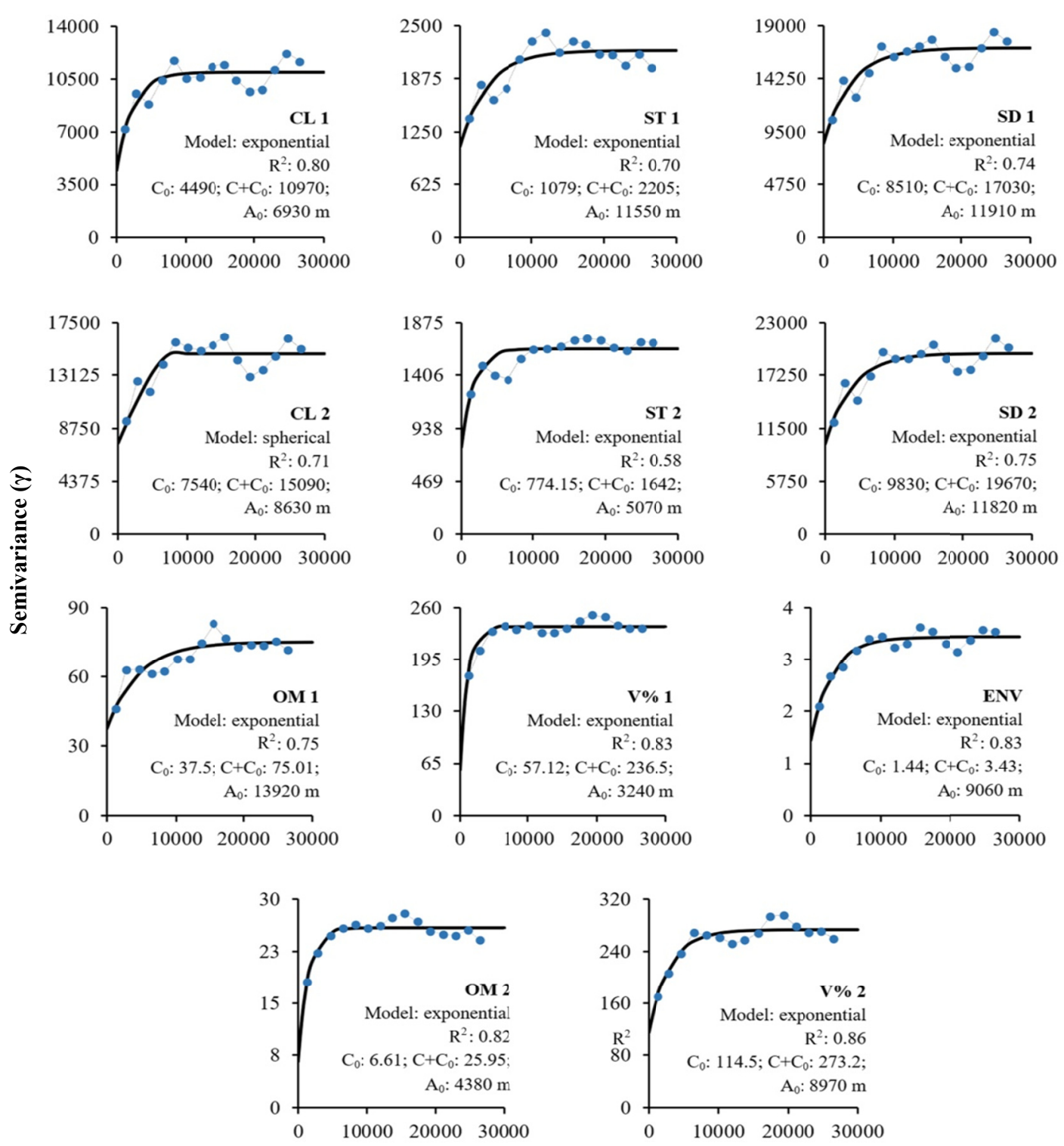

Distance (m)

Figure 3. Simple semivariograms and their respective parameters of the clay contents (CL1 and CL2) sand (SD1 and SD2), silt (ST1 and ST2), organic matter (OM1 and OM2), saturation by bases (V\%1 and V\%2) and environment of production of sugarcane (ENV) 
The semivariance stabilizes when the threshold is reached, thereby defining the range $\left(\mathrm{A}_{0}\right)$ of the experimental semivariograms (Trevisan et al., 2017). It was observed that the soil attributes of the superficial layer $(0.00-0.25$ m) presented ranges above $11550 \mathrm{~m}$, except for CL1 and V\%1 attributes (Figure 3). These attributes tended to a semivariance structure at short distances, between 3240 and $6930 \mathrm{~m}$, due to the textural variation of soils and the fertility management used in the sugarcane cultivation.

In this region of the São Paulo state, soil pH correction through agricultural correctives, e.g., calcium carbonate, occurs in total area, and the amount usually applied is based on a soil analysis from a single sample (composed of 20 samples randomly collected in an area of homogeneous granulometry). Thus, it is presupposing that soil base saturation does not present high variability in crop areas. Different from that observed in the V\%1 semivariogram, it was verified that there is no spatial dependence above $3240 \mathrm{~m}$, which indicates that the conventional sampling of the soil is not appropriate, requiring a greater level of details (Figure 3).

In relation to the $0.25-0.50 \mathrm{~m}$ soil layer, $\mathrm{A}_{0}$ was found between 8630 and $8970 \mathrm{~m}$, for CL2 and V\%2, respectively (Figure 3). The soil physical and fertility condition in this layer was more homogeneous, however, it does not deviate from that observed in the soil superficial layer.

Based on the scaled semivariogram, exponential behavior was observed, being similar to most of the soil physical and chemical attributes and the ENV index (Figures 3 and 4). The low spatial dependence, SDE $>46 \%$, was justified by the low contribution of the structural semivariance and the high nugget effect in the fit of the model (Figure 4). This SDE characteristic in the scaled semivariogram was possibly inherited from attributes ST1, ST2, SD1, SD2, OM1 and V\%2. The semivariance was stabilized at $10322 \mathrm{~m}$, close to the ranges obtained for $\mathrm{A}_{0}$ of SD1, SD2, ST1, OM1 and ENV index (Figure 3).

The fit of the exponential model was satisfactory, with coefficient of determination $\left(\mathrm{R}^{2}\right)$ of 0.70 and SSE close to zero (Figure 4). Similar results were obtained by Oleiveira et al. (2015) and Marques Júnior et al. (2015), in which they obtained exponential scaled semivariograms with $\mathrm{R}^{2}$ between 0.50 and 0.91 , working with soil physical and chemical attributes of the São Paulo state.

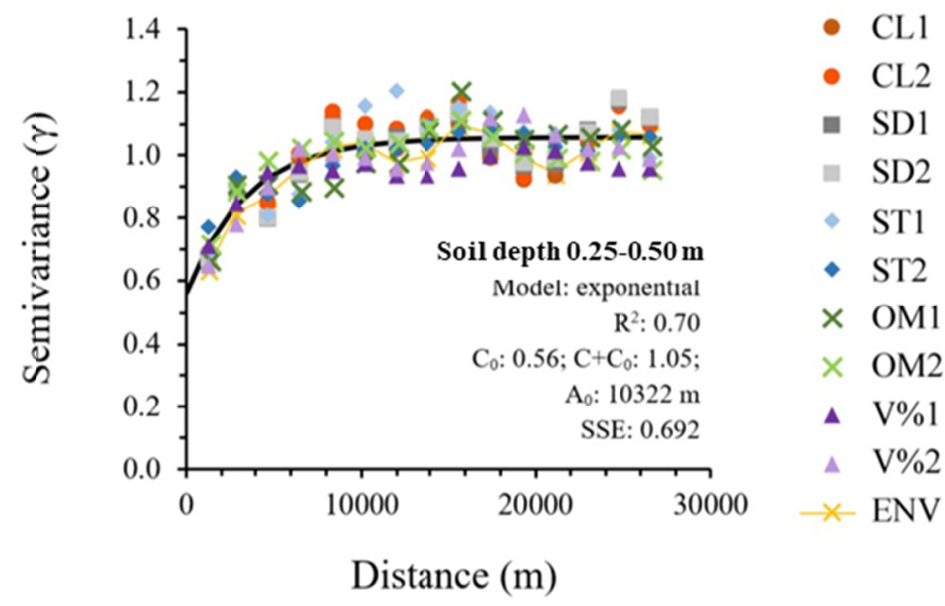

Figure 4. Scaled semivariogram and their respective parameters for the physical and chemical attributes of the soil in the $0-0.50 \mathrm{~m}$ layer and environment of production of sugarcane

The minimum number of samples calculated to determine the spatial variability of the investigated attributes in this study was a sample for each 18.12 ha. This sample must be composed of 20 or more sub-samples, representative of an area cultivated with sugarcane, theoretically homogeneous of 18.12 ha. Marques Júnior et al. (2015), evaluating the levels of aluminum and micronutrients in soils of the São Paulo state, found different densities of sampling, much higher than the present study. In Cuesta basaltic regions, a sample in 50,093 ha, Peripheral Depression, a sample in 44,083 ha and, Atlantic plateau, a sample in 43,448 ha. Such variability is attributed especially to geology, the shape of the landscape and the intensity of the weathering of these sites.

From the kriging maps, it was observed that the highest CL contents occurred near the Paraná and Tietê Rivers, represented by classes above $372 \mathrm{~g} \mathrm{~kg}^{-1}$ for CL1 and $335 \mathrm{~g} \mathrm{~kg}^{-1}$ for CL2, in which they corresponded to 12.37 and $50.43 \%$ of the area, respectively (Figures 5A ans 5B). The contours of these classes comprise the municipalities of Ilha Solteira, Itapura and west of Pereira Barreto, in which they have the lithology 
characterized by basalt spills occurred in the Mesozoic period (IPT, 1980). This layer went through pedogenic processes and formed the soils that today have a clayey or very clayey texture. In a detailed survey of the soils of the "Experimental Campus of Ilha Solteira" conducted by Demattê (1980), it was observed the occurrence in some places with a typical clay dystrophic Red Latosol (Oxisol), reaching values of $620 \mathrm{~g} \mathrm{~kg}^{-1}$ of clay.

It is also observed a spatial correlation between the classes of the ST1 and CL1 maps, in which ST levels between 115 and $43 \mathrm{~g} \mathrm{~kg}^{-1}$ correspond to $\mathrm{CL}<272 \mathrm{~g} \mathrm{~kg}^{-1}$. In the $0.25-0.50 \mathrm{~m}$ layer this spatial correspondence occurs to a lesser extent, the ST contents below $107 \mathrm{~g} \mathrm{~kg}^{-1}$ represented the greater part of the area, $72.5 \%$, while the CL contents in this layer were above $225 \mathrm{~g} \mathrm{~kg}^{-1}$.
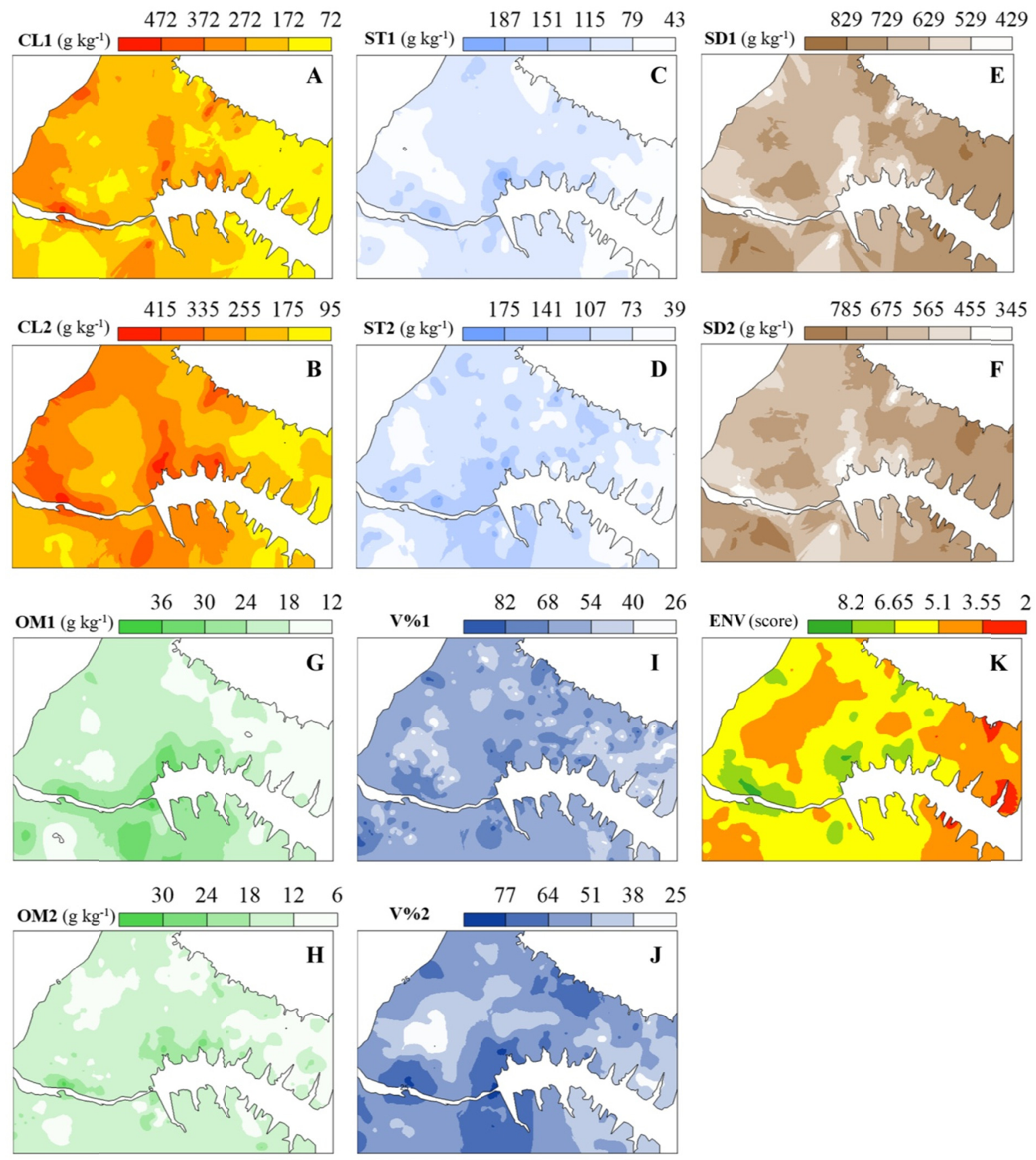

Figure 5. Kriging maps of clay content (A) CL1 and (B) CL2, silt (C) ST1 and (D) ST2, sand (E) SD1 and (F) SD2, soil organic matter (G) OM1 and (H) OM2, and base saturation (I) V\%1 and (J) V\%2 in the 0.00-0.25 and 0.25-0.50 m layers, and environment of production of sugarcane $(\mathrm{K}) \mathrm{ENV}$ 
The highest SD contents occurred near to the dam of the river that cuts the map, represented by classes above $729 \mathrm{~g} \mathrm{~kg}^{-1}$ in the $0.00-0.25 \mathrm{~m}$ layer and above $675 \mathrm{~g} \mathrm{~kg}^{-1}$ in the $0.25-0.50 \mathrm{~m}$ layer, occupying $34.11 \%$ and $42.61 \%$ of the area, respectively (Figures $5 \mathrm{E}$ and $5 \mathrm{~F}$ ). This condition suggests the existence of soils with low agricultural ability. Therefore, the contents of CL at these sites do not exceed $180 \mathrm{~g} \mathrm{~kg}^{-1}$.

High V\% levels occurred in the same region, represented by classes above $68 \%$ for $\mathrm{V} \% 1$ and $64 \%$ for V\%2, corresponding to $10.86 \%$ and $19.24 \%$ of the total area, respectively (Figures $5 \mathrm{I}$ and $5 \mathrm{~J}$ ). These results support the linear correlations obtained between $\mathrm{V} \% \times \mathrm{CL}$ and $\mathrm{OM}$, which, although weak, between $0.26^{* *}$ and $0.44^{* *}$, are justified by spatial distribution. The V\%2 map presented spatial distribution similar to the map of CL2, being soils with the best agricultural aptitude (Figures 5B and 5J).

The spatial distribution of OM indicated levels above $30 \mathrm{~g} \mathrm{~kg}^{-1}$ for OM1 and $24 \mathrm{~g} \mathrm{~kg}^{-1}$ for OM2 near the river, which corresponded to $25.69 \%$ and $5.43 \%$ of the area, respectively. The best OM condition was observed at sites with CL and V\% above $272 \mathrm{~g} \mathrm{~kg}^{-1}$ and $54 \%$ at $0-0.25 \mathrm{~m}$ layer, and above $255 \mathrm{~g} \mathrm{~kg}^{-1}$ and $64 \%$ at the $0.25-0.50 \mathrm{~m}$, respectively. Corroborating with the results of the linear correlation between $\mathrm{OM} \times \mathrm{V} \%$ and CL, indicating that the contribution of organic matter is influenced by the clay content and base saturation in the layer of $0.25-0.50$ m.

The best environments for the sugarcane production were verified in the coastal regions (Figure $5 \mathrm{~K}$ ). It is observed by the spatial distribution of the ENV index by highest occurrence of environments " $A$ ", "B" and "C" representing $65.83 \%$ of the area. In addition, it was verified that $34.17 \%$ of the area presented soils with a score lower than 5, that is, soils with medium to low production potential classified as " $D$ " to " $E$ " environments.

In the comparison between ENV index maps and soil attributes, it can be seen that CL, OM and V\% levels follow the distribution of " $\mathrm{A}$ " and "B" environments with grades above 6.65 (Figures 5K, 5B, 5G and 5J). The CL content also followed the distribution of the production environments, however in an inverse way, that is, the higher the sand content, the worse the production environment. Similar result to the behavior of the simple linear correlation matrix (Table 2). Souza et al. (2010) affirm that spatial variability of soil attributes should be taken into account in agricultural planning to optimize fertilizer applications and increase sugarcane productivity, thus reducing production costs and environmental problems.

\section{Conclusion}

Through the scaled semivariogram it was possible to verify that the sampling density of a sample for each 18 ha can be used for a mapping in macroscale in the northwest region of the state of São Paulo.

The semivariance structures of the soil attributes and index of production environments were better fitted to exponential models, with moderate to high spatial dependence classification and ranges up to $13920 \mathrm{~m}$.

The index based on production environments for sugarcane was positively correlated with the contents of silt, clay, organic matter and saturation by bases, and negatively with the sand content.

The best environments for the production of sugarcane were verified in the coastal regions, due to the higher clay content, organic matter and better soil base saturation, considering the two layers evaluated.

Further sample planning studies should be carried out in other regions and soils with different characteristics from those observed in the present study, in order to verify the influence of the spatial variability of the soil attributes in the appropriate sample grid size.

\section{References}

Cavalcante, E. P., \& do Prado, H. (2010). Ambientes de produção de cana-de-açúcar de latossolos na região de Araxá MG. Nucleus, 7, 115-124. https://doi.org/10.3738/nucleus.v7i2.353

Ceddia, M. B., Vieira, S. R., Villela, A. L. O., Mota, L. S., Anjos, L. H. C., \& Carvalho, D. F. (2009). Topography and spatial variability of soil physical properties. Scientia Agricola, 66, 338-352. https://doi.org/10.1590/S0103-90162009000300009

Comegna, V., \& Basile, A. (1994). Temporal stability of spatial patterns of soil water storage in a cultivated Vesuvian soil. Geoderma, 62, 299-310. https://doi.org/10.1016/0016-7061(94)90042-6

Comissão de Solos. (1960). Levantamento de reconhecimento dos solos do Estado de São Paulo (Boletim 12). Rio de Janeiro, RJ: Ministério da Agricultura, Serviço Nacional de Pesquisas Agronômicas.

CETESB (Companhia Ambiental do Estado de São Paulo). (2008). Valores da Condição de Qualidade dos Solos da Bacia Hidrográfica do Alto Tietê-UGRHI 6 e da Região Metropolitana de São Paulo-RMSP. São Paulo, SP: CETESB. 
CETESB (Companhia Ambiental do Estado de São Paulo). (2015). Qualidade dos solos no estado de São Paulo, bacias hidrográficas dos rios Piracicaba, Capivari e Jundiaí-UGRHI 5. São Paulo, SP: CETESB.

CONAB (Companhia Nacional de Abastecimento). (2017). Acompanhamento da safra brasileira, Cana-de-açúcar-V.3 Safra 2016/2017-N.4-Quarto levantamento. Brasília, DF: CONAB.

Crusciol, C. A. C., Foltran, R., Rossato, O. B., McCray, J. M., \& Rossetto, R. (2014). Effects of surface application of calcium-magnesium silicate and gypsum on soil fertility and sugarcane yield. Revista Brasileira de Ciência do Solo, 38, 1843-1854. https://doi.org/10.1590/S0100-06832014000600019

Demattê, J. L. I. (Eds.). (1980). Levantamento detalhado dos solos do campus experimental de Ilha Solteira. Piracicaba, SP: Esalq/USP.

EMBRAPA (Empresa Brasileira de Pesquisa Agropecuária). (2011). Manual de métodos de análise de solo. Rio de Janeiro, RJ: Centro Nacional de Pesquisa de Solos.

EMBRAPA (Empresa Brasileira de Pesquisa Agropecuária). (2013). Sistema brasileiro de classificação de solos. Brasília, DF: Embrapa Brasília.

Ferreyra, R. A., Apezteguia, H. P., Sereno, R., \& Jones, J. W. (2002). Reduction of soil water spatial sampling density using scaled semivariograms and simulated annealing. Geoderma, 110, 265-289. https://doi.org/ 10.1016/S0016-7061(02)00234-3

Garbiate, M. V., Tadeu Vitorino, A. C., Andrade Tomasini, B., Bergamin, A. C., \& Panachuki, E. (2011). Erosão entre sulcos em área cultivada com cana crua e queimada sob colheita manual e mecanizada. Revista Brasileira de Ciência do Solo, 35, 2145-2155. https://doi.org/10.1590/S0100-06832011000600029

Goldemberg, J., Mello, F. F., Cerri, C. E., Davies, C. A., \& Cerri, C. C. (2014). Meeting the global demand for biofuels in 2021 through sustainable land use change policy. Energy Policy, 69, 14-18. https://doi.org/ 10.1016/j.enpol.2014.02.008

IPT (Instituto de Pesquisas Tecnológicas do Estado de São Paulo). (1981). Mapa geológico do Estado de São Paulo: Escala 1:500,000. São Paulo, SP: Instituto de Pesquisas Tecnológicas do Estado de São Paulo, Divisão de Minas e Geologia Aplicada.

Liu, Y., Lv, J., Zhang, B., \& Bi, J. (2013). Spatial multi-scale variability of soil nutrients in relation to environmental factors in a typical agricultural region, Eastern China. Science of the Total Environment, 450, 108-119. https://doi.org/10.1016/j.scitotenv.2013.01.083

Marques Jr., J., Alleoni, L. R. F., Teixeira, D. D. B., Siqueira, D. S., \& Pereira, G. T. (2015). Sampling planning of micronutrients and aluminium of the soils of São Paulo, Brazil. Geoderma Regional, 4, 91-99. https://doi.org/10.1016/j.geodrs.2014.12.004

Montanari, R., Carvalho, M. D. P., Andreotti, M., Dalchiavon, F. C., Lovera, L. H., \& Oliveira Honorato, M. A. D. (2010). Aspectos da produtividade do feijão correlacionados com atributos físicos do solo sob elevado nível tecnológico de manejo. Revista Brasileira de Ciência do Solo, 34, 1811-1822. https://doi.org/10.1590/ S0100-06832010000600005

Montanari, R., Souza, G. S. A., Pereira, G. T., Marques, J., Siqueira, D. S., \& Siqueira, G. M. (2012). The use of scaled semivariograms to plan soil sampling in sugarcane fields. Precision Agriculture, 13, $542-552$. https://doi.org/10.1007/s11119-012-9265-6

Oliveira, I. A., Marques Junior, J., Costa Campos, M. C., de Aquino, R. E., de Freitas, L., Silva Siqueira, D., \& da Cunha, J. M. (2015). Variabilidade espacial e densidade amostral da suscetibilidade magnética e dos atributos de Argissolos da Região de Manicoré, AM. Revista Brasileira de Ciência do Solo, 39, 668-681. https://doi.org/10.1590/01000683rbcs20140496

Oliveira, I. R., Teixeira, D. B., Panosso, A. R., Camargo, L. A., Marques Júnior, J., \& Pereira, G. T. (2013). Modelagem geoestatística das incertezas da distribuição espacial do fósforo disponível no solo, em área de cana-de-açúcar. Revista Brasileira de Ciência do Solo, 37, 1481-1491. https://doi.org/10.1590/S0100-0683 2013000600005

Oliveira, I. A., Campos, M. C. C., de Aquino, R. E., Júnior, J. M., de Freitas, L., \& de Souza, Z. M. (2014). Semivariograma escalonado no planejamento amostral da resistência à penetração e umidade de solo com cana-de-açúcar. Revista de Ciências Agrárias/Amazonian Journal of Agricultural and Environmental Sciences, 57, 287-296. https://doi.org/10.4322/rca.ao1421 
Pimentel-Gomes, F., \& Garcia, C. H. (Eds.). (2002). Estatística aplicada a experimentos agronômicos e florestais: Exposição com exemplos e orientações para uso de aplicativos. Piracicaba, SP: Fealq.

Segnini, A., Carvalho, J. L. N., Bolonhezi, D., Milori, D. M. B. P., Silva, W. T. L. D., Simões, M. L., ... Martin-Neto, L. (2013). Carbon stock and humification index of organic matter affected by sugarcane straw and soil management. Scientia Agricola, 70, 321-326. https://doi.org/10.1590/S0103-90162013000500006

Souza, Z. M. D., Cerri, D. G. P., Colet, M. J., Rodrigues, L. H. A., Magalhães, P. S. G., \& Mandoni, R. J. A. (2010). Análise dos atributos do solo e da produtividade da cultura de cana-de-açúcar com o uso da geoestatística e árvore de decisão. Ciência Rural, 40, 840-847. https://doi.org/10.1590/S0103-84782010 005000048

Strassburg, B. B., Latawiec, A. E., Barioni, L. G., Nobre, C. A., da Silva, V. P., Valentim, J. F., ... Assad, E. D. (2014). When enough should be enough: Improving the use of current agricultural lands could meet production demands and spare natural habitats in Brazil. Global Environmental Change, 28, 84-97. https://doi.org/10.1016/j.gloenvcha.2014.06.001

Trevisan, R. G., Freddi, O. S., Wruck, F. J., Tavanti, R. F. R., \& Peres, F. S. C. (2017). Variability of physical properties of soil and rice grown under cover crops in crop-livestock integrated system. Bragantia, 76, 145-154. https://doi.org/10.1590/1678-4499.596

Van Raij, B., Andrade, J. C., Cantarella, H., \& Quaggio, J. A. (2001). Análise química para avaliação da fertilidade de solos tropicais. Campinas, SP: Instituto Agronômico.

Vieira, S. R., Falci Dechen, S. C., Machado Siqueira, G., \& Dufranc, G. (2011). Variabilidade espacial de atributos físicos e químicos relacionados com o estado de agregação de dois Latossolos cultivados no sistema de semeadura direta. Bragantia, 70, 185-195. https://doi.org/10.1590/S0006-87052011000100025

Vieira, S. R., Nielsen, D. R., \& Biggar, J. W. (1981). Spatial Variability of Field-Measured Infiltration Rate 1. Soil Science Society of America Journal, 45, 1040-1048. https://doi.org/10.2136/sssaj1981.036159950045 $00060007 \mathrm{x}$

Zhao, D., Glaz, B., \& Comstock, J. C. (2010). Sugarcane response to water-deficit stress during early growth on organic and sand soils. American Journal of Agricultural and Biological Sciences, 5, 403-414. https://doi.org/10.3844/ajabssp.2010.403.414

\section{Copyrights}

Copyright for this article is retained by the author (s), with first publication rights granted to the journal.

This is an open-access article distributed under the terms and conditions of the Creative Commons Attribution license (http://creativecommons.org/licenses/by/4.0/). 